УДК 159.923.2-055.2-053.81

DOI https://doi.org/10.26661/2310-4368/2021-4-12

\title{
ОСОБИСТІСНІ УМОВИ ЗАДОВОЛЕНОСТІ ОБРАЗОМ ФІЗИЧНОГО Я У ЖІНОК РАННЬОГО ДОРОСЛОГО ВІКУ
}

\author{
Шевченко Н. Ф. \\ доктор психологічних наук, професор, \\ завідувач кафедри педагогіки та психології освітньої діяльності \\ Запорізький національний університет \\ вул. Жуковського, 66, Запоріжжя, Україна \\ orcid.org/0000-0002-5297-6588 \\ shevchenkonf.20@gmail.com
}

\begin{abstract}
Ключові слова: образ Я, образ фізичного Я, задоволеність зовнішністю, самоставлення, перфекиіонізм, психологічне благополуччя.
\end{abstract}

У статті наведено результати емпіричного дослідження особистісних умов задоволеності образом фізичного Я у жінок раннього дорослого віку. Я-образ розглянуто як систему, що включає три компоненти: когнітивний (знання про самого себе); афективний (ставлення до себе, самооцінка); поведінковий (конкретні дії, які можуть бути викликані образом Я), а образ фізичного Я-як образ зовнішнього вигляду. Незадоволеність зовнішністю визначено як конфлікт між реальним та ідеальним образом фізичного Я, тобто між суб'єктивною оцінкою зовнішності на певний момент й уявленням про ідеальний зовнішній вигляд. На підставі теоретичного аналізу особистісної детермінації задоволеності зовнішністю, а також враховуючи соціальну ситуацію розвитку в ранньому дорослому віці та структурну організацію Я-образу, було виокремлено особистісні умови задоволеності образом фізичного Я у жінок раннього дорослого віку: позитивне самоставлення, прояви перфекціонізму, психологічне благополуччя особистості. Емпірично досліджено задоволеність образом фізичного Я за параметрами висоти самооцінки реального та ідеального образу фізичного Я. Конкретизовано роль образів реальної й ідеальної зовнішності у визначенні рівня задоволеності зовнішністю, що залежить від адекватності висоти самооцінок. Вивчено структуру самоставлення жінок раннього дорослого віку. Отримані дані засвідчили, що задоволеність образом фізичного Я впливає на загальне позитивне ставлення особистості до себе (самоповагу, аутосимпатію, самоінтерес, очікуване ставлення від навколишніх). Аналіз рівня перфекціонізму показав, що досліджувані жінки висувають високі стандарти особистості до себе, постійно оцінюють свою поведінку, мають мотив прагнення до досконалості; висувають високі стандарти і нереалістичні вимоги не тільки до себе, а й до інших. Вивчено ступінь прояву основних показників психологічного благополуччя особистості (позитивні відносини з іншими, автономія, управління оточенням, особистісне зростання, мета в житті, самосприйняття). Отримані дані засвідчили, що задоволеність образом фізичного Я впливає на загальне психологічне благополуччя особистості. За допомогою множинного регресивного аналізу встановлено, що на позитивну самооцінку (задоволеність) образу фізичного Я прямо впливають компоненти психологічного благополуччя (самосприйняття, мета в житті, особистісне зростання), компоненти самоставлення (самоповага, самоінтерес) і перфекціонізму (перфекціонізм, орієнтований на себе). 


\title{
PERSONAL CONDITIONS OF SATISFACTION WITH THE PHYSICAL SELF-IMAGE IN EARLY ADULT WOMEN
}

\author{
Shevchenko N. F. \\ Doctor of Psychological Sciences, Professor, \\ Head of the Department of Pedagogics and Psychology of Education \\ Zaporizhzhia National University \\ Zhukovsky str., 66, Zaporizhzhya, Ukraine \\ orcid.org/0000-0002-5297-6588 \\ shevchenkonf.20@gmail.com
}

Key words: self-image, physical self-image, appearance satisfaction, self-attitude, perfectionism, psychological well-being.
The article presents the results of an empirical study of personal conditions of satisfaction with the physical self-image in early adult women. Self-image has been considered as a system that includes three components: cognitive (knowledge of own self); affective (attitude, self-esteem); behavioral (specific actions that can be caused by the image of the self), and the image of the physical self - as an image of one's own appearance. Dissatisfaction with appearance has been defined as a conflict between the real and the ideal image of the physical self; the subjective assessment of appearance at the moment, and the idea of the ideal appearance. Based on the theoretical analysis of personal determination of appearance satisfaction, social situation of development in early adulthood and structural organization of the self-image, the authors have highlighted the personal conditions of satisfaction with the physical self-image in early adulthood: positive self-esteem, perfectionism, psychological wellbeing of an individual. Satisfaction with the physical self-image has been empirically studied according to the parameters of the height of self-esteem of the real and ideal images of the physical Self. The authors have specified the role of images of real and ideal appearance in determining the level of satisfaction with appearance, which depends on the adequacy of the selfesteem height. The self-attitude structure of women of early adulthood has been studied. The obtained data has shown that satisfaction with the physical self-image affects the overall positive attitude of the individual (self-esteem, self-sympathy, self-interest, expected attitude from others). Research of the perfectionism level has shown that the studied women set high standards of personality in relation to themselves, constantly evaluate their behavior, have a motive for striving for perfection; set high standards and unrealistic demands not only on themselves but also on others. Manifestation of the main indicators of psychological individual well-being (positive relationships with others, autonomy, environmental management, personal growth, purpose in life, self-acceptance) have been studied. The obtained data have testified that satisfaction with the physical self-image affects the overall psychological wellbeing of an individual. The multiple regression analysis has witnessed that the positive self-esteem (satisfaction) of the physical self is directly influenced by the components of psychological well-being (self-acceptance, purpose in life, personal growth), components of self-esteem (self-esteem, self-interest) and perfectionism (self-centered perfectionism).
Вступ. Актуальність дослідження образу фізичного Я зумовлена тим, що в сучасному стандарті успішної особистості тілесна краса займає одне $з$ чільних місць. На свідомість багатьох жінок чинять сильний вплив стереотипні уявлення про фізично розвинене гарне тіло, що має певні пропорції і форми; у свідомості більшості штучно завищується значущість зовнішності, незалежно від соціальної ролі та статусу носія. Оформлення зовнішності відповідно до заданого суспільством 
стандарту стає більш значущим, ніж фізичний вигляд зі своїми конституціональними і функціональними особливостями, які часто йдуть врозріз 3 соціокультурними вимогами краси. Незадоволеність зовнішністю поширюється настільки, що стає властивою не тільки особам із реальними дефектами зовнішності та людям зрілого віку, але й більш молодому населенню, несучи потенційну загрозу фізичному і психічному здоров’ю.

Ідеальний образ успішної, привабливої особистості формується цілими інститутами краси, здоров'я і моди, які, з одного боку, популяризують цей недосяжний образ, а з іншого - одразу ж пропонують пристосувальні способи перетворення зовнішності для іiі наближення до заданого ідеалу. Таким чином, дедалі більшою популярністю користується пластична хірургія, дотримання різних дієт і тілесних практик із корекції тіла, що призводить до процвітання індустрій краси, моди і ще більшого посилення ідеалу. Перебуваючи під таким негативним соціальним впливом, індивід виявляється в положенні незадоволеності собою i змушений вдаватися до адаптаційно-компенсаторних стратегій перетворення своєї зовнішності, таким чином пристосовуючись до образу фізичного Я, що нав'язується суспільством.

$\mathrm{У}$ сучасних дослідженнях із цієї проблеми під незадоволеністю образом фізичного Я розуміється наявність у людини негативних думок i почуттів щодо власної зовнішності. Це явище має на увазі якусь невідповідність між тим, як людина сприймає своє тіло, та їі уявленнями про тіло ідеальне. Конфлікт між уявленням про себе і реальним досвідом $\epsilon$ перешкодою на шляху до здорового функціонування та розвитку особистості.

Аналіз наукової літератури показав різноманіття досліджень образу фізичного Я, основним об'єктом уваги яких є вивчення причинно-наслідкової обумовленості (культурної, соціальної, гендерної, вікової) задоволеності зовнішністю, психологічних наслідків незадоволеності образом фізичного Я (Н. Рамсі, Д. Харкорт [5]; В. Суемі, А. Фернхем [7]).

У соціально-психологічних дослідженнях образ фізичного Я розглядається як соціально-психологічний феномен (Є.А. Варлашкіна [1], А.О. Гавриленко [2] тощо), інтегрований в різноманітні аспекти соціального буття особистості.

Водночас аналіз літератури засвідчив, що переважна кількість досліджень образу фізичного Я стосується осіб юнацького віку (І.М. Левицька [4], А.Г. Черкашина [9]), залишаючи поза увагою інші вікові періоди. Зокрема, актуальність вивчення особистісних умов задоволеності образом фізичного Я у жінок дорослого віку полягає в необхідності психологічного супроводу жінок із метою розширення усвідомленого ставлення до своєї зовнішності, формування адекватного уявлення про себе, підвищення якості життя особистості в умовах адаптації до сучасного соціального середовища.

Мета статті - представити результати емпіричного дослідження особистісних умов задоволеності образом фізичного Я у жінок раннього дорослого віку.

Виклад основного матеріалу. Традиційно у психології проблема образу фізичного Я особистості розглядається в контексті ідей психології самосвідомості. У сучасній психології самосвідомість розуміється як складний психічний процес, сутність якого полягає в сприйнятті особистістю численних образів самої себе в різних ситуаціях діяльності та поведінки, в усіх формах взаємодії з іншими людьми і в поєднанні цих образів в єдине цілісне утворення - поняття Я, власної індивідуальності. Загальною закономірністю різноманітних авторських поглядів на природу самосвідомості $\epsilon$ визнання науковцями образу фізичного Я одним із іiі структурних компонентів. Я-образ - це установча система, що включає три компоненти: когнітивний (знання про самого себе); афективний (ставлення до себе, самооцінка); поведінковий (конкретні дії, які можуть бути викликані образом Я) [3; 6].

Під образом фізичного Я розуміється образ зовнішнього вигляду особистості. Ми поділяємо тезу В.Г. Сахарової про те, що, оцінюючи власне тіло, визнаючи задоволеність або незадоволеність ним, людина насамперед оцінює свою зовнішність (образ) і тільки потім - фізичний стан тіла [6, с. 19].

Під незадоволеністю зовнішністю мається на увазі конфлікт між реальним та ідеальним образом фізичного Я, тобто між суб'єктивною оцінкою зовнішності на певний момент й уявленням про ідеальний зовнішній вигляд. Що сильніша неузгодженість між цими образами, то вища незадоволеність зовнішністю. Формування, розвиток, функціонування і трансформації сформованого образу тіла корелюють з закономірностями психічного і соматичного індивідуального розвитку людини залежно від вікового етапу, але на кожному віковому етапі - на якісно різних рівнях. Ставлення до зовнішнього вигляду разом із віковими факторами також пов'язане 3 життєвими подіями і роллю, яка відводиться зовнішньому вигляду в цих подіях. Ставлення особистості до зовнішнього вигляду на певних етапах життєвого шляху змінюється, відповідно до того, наскільки вигляд допомагає досягненню цілей життєдіяльності [5].

Негативні емоції, що виникають в разі незадоволеності власною зовнішністю, призводять до порушення цілісності Я, породжуючи вну- 
трішньоособистісні конфлікти та деструктивні стосунки з буттям, трансформують ціннісну картину світу.

На підставі теоретичного аналізу особистісної детермінації задоволеності зовнішністю, а також враховуючи соціальну ситуацію розвитку в ранньому дорослому віці та структурну організацію Я-образу [1; 2; 7; 9-11], було виокремлено особистісні умови задоволеності образом фізичного Я у жінок раннього дорослого віку: позитивне самоставлення, прояви перфекціонізму, психологічне благополуччя особистості.

Самоставлення $є$ цілісним, одновимірним та універсальним утворенням, що виражає ступінь позитивного ставлення індивіда до образу власного Я, є інтеграцією окремих самооцінок. Образ фізичного Я - це динамічний феномен, він завжди $\epsilon$ усвідомлюваним особистістю в тимчасовому аспекті. Сенситивність жінок до вікових змін зовнішності, незадоволеність образом фізичного Я залежить від неузгодженості позитивного самоставлення й усвідомлення неминучості втрати зовнішньої привабливості [4].

Перфекціонізм є стійкою особистісною якістю, що активно виявляється в різноманітних формах психічної активності особистості (мотиваційній та емоційній сферах, поведінці, саморегуляції, самоактуалізації, відповідальності, копінг-стратегії, самооцінці, самоефективності, тимчасовій перспективі, задоволеності життям тощо). Прагнення до фізичної досконалості може зумовлюватися впливом соціально запропонованого перфекціонізму на образ фізичного Я особистості [8; 12].

Психологічне благополуччя $\epsilon$ суб'єктною характеристикою особистості, резервом активності та здійснення діяльності; займає центральне місце в самосвідомості, взаємопов'язане з образом Я особистості; визначає якісні характеристики самоставлення в широкому класі життєвих ситуацій; $є$ індивідуальним критерієм оцінки самоефективності, успішності, самореалізації, саморозвитку; відображає загальне відчуття задоволеності життям; пов'язане 3 проявом різних особистісних феноменів. Тому актуальним напрямом дослідження особистісної детермінації задоволеності образом фізичного Я у жінок в період дорослості визначено вивчення психологічного благополуччя [1].

В основу дослідження покладено припущення про те, що задоволеність образом фізичного Я у жінок раннього дорослого віку визначається комплексом взаємопов'язаних особистісних умов (позитивним самоставленням, проявом перфекціонізму, психологічним благополуччям особистості).

Емпіричне дослідження особистісних умов задоволеності образом фізичного Я у жінок раннього дорослого віку проводилося на базі салону
«Lash Brow House» м. Запоріжжя. У дослідженні взяли участь 30 жінок раннього дорослого віку (21-35 років).

Психодіагностичний інструментарій становили методики: «Методика діагностики самооцінки» (Т.В. Дембо, С.Я. Рубінштейн); «Багатовимірна шкала перфекціонізму» (П. Хьюітт, Г. Флетт; адапт. І.І. Грачьової); «Шкала психологічного благополуччя» (К. Ріфф; адапт. Л.А. Пергаменщика, М.М. Лепешинського); «Опитувальник самоставлення» (В.В. Столін, С.Р. Пантилеєв).

Перейдемо до результатів дослідження особистісних умов задоволеності образом фізичного Я у жінок раннього дорослого віку.

Задоволеність образом фізичного Я вивчалася за «Методикою діагностики самооцінки» (Т.В. Дембо, С.Я. Рубінштейн), зокрема за шкалою «Зовнішність»; оцінювалися такі параметри: висота самооцінки реального та ідеального образу фізичного Я, а також розбіжності між ними як прояв задоволеності/незадоволеності зовнішністю. Вибірка досліджуваних була розділена на групи. Критерієм формування груп став рівень задоволеності образом фізичного Я: низький (1 група), середній (2 група), високий (3 група). Наявність відмінностей між групами обчислювалася за допомогою t-критерію Стьюдента. Під час порівняння показників розбіжності самооцінок реального та ідеального образу фізичного Я досліджуваних зі значенням норми виявлена незадоволеність образом фізичного Я у 6 осіб, що становить $20 \%$ досліджуваних вибірки $(\mathrm{t}=3,16$; $\mathrm{p} \leq 0,01$ - I група). Середній рівень задоволеності образом фізичного Я властивий 17 досліджуваним (II група) - 56,67\% вибірки. Високий рівень задоволеності образом фізичного Я властивий 7 респондентам - 23,33\% вибірки $(\mathrm{t}=3,75 ; \mathrm{p} \leq 0,01$ III група).

Згідно 3 отриманими даними незадоволеність образом фізичного Я залежить від заниженої самооцінки реального образу фізичного Я $(\mathrm{t}=3,04 ; \mathrm{p} \leq 0,01)$ у більшості досліджуваних I групи $(67 \%)$ і високої самооцінки ідеального образу фізичного Я (25\%). Виявлена закономірність свідчить про конфлікт між низькою самооцінкою реального та високою самооцінкою ідеального образів фізичного Я, про невдоволення i дискомфорт в емоційній сфері жінок, які не задоволені своєю зовнішністю.

За середнього (адекватного) рівня задоволеності образом фізичного Я (II група) конфлікту між самооцінкою реального й ідеального образів фізичного Я не виявлено. Більшість досліджуваних адекватні в оцінці реального $(70 \%)$ та ідеального (53\%) образів фізичного Я. Це дає підстави припустити, що жінки, задоволені образом фізичного Я, приймають свій зовнішній вигляд, 
усвідомлюють його «сильні» і «слабкі» сторони, відчувають емоційний комфорт під час оцінки своєї зовнішності.

III група з високим рівнем задоволеності образом фізичного Я характеризується великою кількістю респондентів (64\%) із завищеною самооцінкою реального образу фізичного Я щодо норми $(\mathrm{t}=2,64 ; \mathrm{p} \leq 0,01)$. На відміну від I і II груп у $29 \%$ респондентів показник самооцінки ідеального образу фізичного Я є меншим у вибірці. Отже, жінки повністю задоволені образом фізичного Я і не мають наміру щось кардинально змінювати в своєму зовнішньому вигляді.

Таким чином, отримані результати підтверджують думку дослідників про роль самооцінки реального й ідеального образів у формуванні задоволеності образом фізичного Я $[1 ; 5 ; 9 ; 11]$. Аналіз конкретизував роль образів реальної та ідеальної зовнішності у визначенні рівня задоволеності зовнішністю, що залежить від адекватності висоти самооцінок. Незадоволеність зовнішністю зумовлена неадекватно заниженою самооцінкою реального образу і високою самооцінкою ідеального образу фізичного Я. Адекватність висоти самооцінки реального та ідеального образів фізичного Я $є$ визначальним фактором середнього (адекватного) рівня задоволеності зовнішністю. Високий рівень задоволеності зовнішністю залежить від завищеної самооцінки реального образу фізичного Я і високої самооцінки ідеального образу фізичного Я.

За допомогою опитувальника В.В. Століна було вивчено структуру самоставлення, яка представлена чотирма емоційними компонентами (самоповагою, аутосимпатією, самоінтересом, очікуваним ставленням від навколишніх), а також узагальненим фактором «глобального самоставлення» (почуття «за» або «проти» себе).

Згідно з отриманими даними у досліджуваних 3 низьким рівнем задоволеності образом фізичного Я (I група) зафіксовано показники самоповаги в межах середнього рівня (7,18 бала; $44,67 \%)$. У респондентів II групи цей показник становив 8,23 бала, що дорівнює 58,67\%. У досліджуваних із високим рівнем задоволеності образом фізичного Я (III група) показник самоповаги виявився найбільшим - 13,48 бала (93,67\%). Самоповага передбачає внутрішню послідовність, саморозуміння, самовпевненість. Самоповага як аспект самоставлення емоційно і змістовно об'єднує віру в свої сили, здібності, енергію, самостійність, оцінку своїх можливостей контролювати власне життя і бути самопослідовним, розуміння самого себе.

За шкалою аутосимпатії, що відображає дружність/ворожість (самосприйняття/самозвинувачення) до власного «Я», найвищі показники також зафіксовано у III групі досліджуваних $(9,01$ бала, що становить $69,67 \%)$. Показники в межах низького рівня виявлено у жінок із низьким рівнем задоволеності образом фізичного Я (I група: 3,44 бала, що становить 16\%). Досить високі показники зафіксовано в респондентів із помірним рівнем задоволеності образом фізичного Я (II група: 5,78 бала, що становить 37,33\%). У змістовному плані аутосимпатія на позитивному полюсі об'єднує схвалення себе загалом і в істотних деталях, довіру до себе і позитивну самооцінку, на негативному полюсі - бачення в собі переважно недоліків, низьку самооцінку, готовність до самозвинувачення. Пункти свідчать про такі емоційні реакції на себе, як роздратування, презирство, глузування, винесення самовироку.

Інтерес до себе на досить високому рівні властивий жінкам усіх досліджуваних груп: I група - 6,03 бала (71,33\%); II група - 6,29 бала $(71,33 \%)$; III група - 7,05 бала $(92,33 \%)$. Самоінтерес відображає ступінь близькості до самого себе, зокрема інтерес до власних думок і почуттів, готовність спілкуватися з собою «на рівних», впевненість у своїй цікавості для інших.

За шкалою очікуваного ставлення від інших найвищі показники зафіксовано у III групі досліджуваних (12,11 бала, що становить 91,33\%). Показники в межах низького рівня виявлено у жінок із низьким рівнем задоволеності образом фізичного Я (І група: 6,15 бала, що становить 9\%). Показники в межах середнього рівня зафіксовано у респондентів із помірним рівнем задоволеності образом фізичного Я (II група: 9,9 бала, що становить $53 \%$ ). Очікуване ставлення від інших відображає очікування позитивного або негативного ставлення до себе навколишніх.

За шкалою глобального самоставлення в досліджуваних із низьким рівнем задоволеності образом фізичного Я (І група) зафіксовано показники в межах середнього рівня (11,43 бала; 38,33\%). У респондентів II групи цей показник становив 15,38 бала, що дорівнює $69,33 \%$. У досліджуваних із високим рівнем задоволеності образом фізичного Я (III група) показник глобального самоставлення виявився найвищим - 24,74 бала (96\%). Глобальне самоставлення - це внутрішньо недиференційоване почуття «за» $\mathrm{i}$ «проти» самого себе. Отримані дані свідчать про те, що задоволеність образом фізичного Я впливає на загальне позитивне ставлення особистості до себе. Що вищий рівень задоволеності образом фізичного Я, то більший рівень емоційних компонентів самоставлення: самоповаги, аутосимпатії, самоінтересу, очікуваного ставлення від навколишніх.

За методикою П. Хьюітта, Г. Флетта було досліджено рівень перфекціонізму жінок та його складники. 
За шкалою «Перфекціонізм, орієнтований на себе» зафіксовано показники в межах високого рівня в досліджуваних усіх груп: I група - 83,35 бала; II група - 72,03 бала; III група - 81,89 бала. Отримані дані свідчать про те, що досліджувані жінки, незалежно від рівня задоволеності образом фізичного Я, висувають високі стандарти особистості до себе, постійно оцінюють та цензурують свою поведінку, а також прагнуть до досконалості. Слід зауважити, що найвищі результати виявлено в жінок I групи.

За шкалою «Перфекціонізм, орієнтований на інших» також виявлено високі показники в досліджуваних усіх груп: I група - 66,04 бала; II група 65,1 бала; III група - 67,2 бала. Результати вказують на те, що жінки висувають високі стандарти i нереалістичні вимоги не лише до себе, а й до інших. Високі бали за цією шкалою передбачають переконання й очікування щодо здібностей інших та наголошують на винятковій важливості їх досконалості.

За шкалою «Соціально приписаний перфекціонізм» зафіксовано показники в межах середнього рівня в усіх досліджуваних групах: I група - 60,01 бала; II група - 59,42 бала; III група - 58,31 бала. Соціально приписаний перфекціонізм характеризує генералізоване переконання або відчуття, що інші висувають до суб'єкта нереалістичні вимоги, яким важко, але необхідно відповідати, щоб заслужити схвалення і прийняття. Згідно з отриманими даними респонденти здебільшого висувають високі вимоги до себе та інших, ніж мають потребу відповідати стандартам навколишніх.

За допомогою методики К. Ріфф було досліджено ступінь вираженості основних показників психологічного благополуччя особистості.

За шкалою «Позитивні відносини 3 іншими» зафіксовано показники в межах середнього рівня в усіх досліджуваних групах: I група - 68,01 бала; II група - 66,32 бала; III група - 65,81 бала. Такі дані вказують на те, що респонденти загалом мають задовільні відносини 3 навколишніми; зазвичай піклуються про добробут інших; здатні співпереживати, допускають прихильності та близькі стосунки; розуміють, що людські відносини будуються на взаємних поступках.

За шкалою «Автономія» виявлено високі показники у респондентів усіх груп: І група - 66,34 бала; II група - 66,41 бала; III група - 68,3 бала. Високі бали за цією шкалою характеризують опитуваних як самостійних та незалежних, здатних протистояти спробам суспільства змусити думати і діяти певним чином. Вони самостійно регулюють власну поведінку; оцінюють себе відповідно до особистих критеріїв.
Числові показники за шкалою «Управління оточенням» виявилися в діапазоні середнього рівня: I група - 67,83 бала; II група - 65,98 бала; III група - 61,04 бала. Як видно, найвищі бали у досліджуваних жінок I групи, які незадоволені образом фізичного Я. Отримані результати характеризують респондентів, які мають владу і компетенцію в управлінні оточенням; контролюють всю зовнішню діяльність; ефективно використовують можливості, що надаються; здатні створювати умови й обставини, які підходять для задоволення особистих потреб та досягнення цілей.

За шкалою «Особистісне зростання» виявлено високі показники у досліджуваних жінок: I група - 72,2 бала; II група - 71,87 бала; III група 76,52 бала. Найвищі бали за шкалою - у жінок III групи, які задоволені образом фізичного Я. Високі бали вказують на те, що особи сприймають себе «зростаючими» і такими, що розвиваються та самореалізовуються. Вони відкриті до нового досвіду, відчувають реалізацію свого потенціалу, спостерігають поліпшення в собі та своїх діях із плином часу, змінюються відповідно до своїх знань і досягнень.

Числові показники за шкалою «Мета в житті» в межах високого рівня зафіксовано лише в III групі респондентів (77,01 бала), у I та II групах - в межах середнього рівня $(72,48$ та 71,92 бала, відповідно). Високі бали за цією шкалою свідчать про наявність мети у житті і почуття спрямованості; вони вважають, що минуле і справжнє життя має сенс; дотримуються переконань, які є джерелами мети у житті; мають наміри та цілі на все життя.

За шкалою «Самосприйняття» також високі бали зафіксовано лише в III групі респондентів (72,21 бала), у I та II групах - в межах середнього рівня (68,03 та 69,45 бала, відповідно). Високі бали характеризують респондентів як осіб, що позитивно ставляться до себе, знають і приймають різні сторони, включаючи гарні та погані якості, позитивно оцінюють своє минуле. Досліджувані I та II груп більше незадоволені собою, відчувають занепокоєння з приводу деяких особистих якостей.

Загальний показник за методикою становив: I група - 412 балів (середній рівень); II група - 411,95 балів (середній рівень); III група 420,89 балів (високий рівень). Отримані дані свідчать про те, що задоволеність образом фізичного Я впливає на загальне психологічне благополуччя особистості. Що вищий рівень задоволеності образом фізичного Я, то вищий рівень психологічного благополуччя і його складників.

Для перевірки гіпотези дослідження застосовувався множинний регресійний аналіз. Цей статистичний метод дозволяє вивчити комп- 
лексний вплив незалежних змінних (у нашому дослідженні ними були компоненти самоставлення, перфекціонізму, психологічного благополуччя особистості) на залежну змінну (задоволеність образом фізичного Я).

До аналізу були включені такі предиктори: самоповага; аутосимпатія; самоінтерес; очікуване ставлення від інших; перфекціонізм, орієнтований на себе; перфекціонізм, орієнтований на інших; соціально приписаний перфекціонізм; позитивні відносини з іншими; автономія; управління оточенням; особистісне зростання; мета в житті; самосприйняття; залежна змінна - задоволеність образом фізичного Я. За ймовірності F-включення $\leq 0,050$ (F-виключення $\geq 0,100$ ) у рівняння регресії увійшли 6 предикторів: сапосприйняття; мета в житті; особистісне зростання; самоповага; самоінтерес; перфекціонізм, орієнтований на себе.

Коефіцієнт множинної кореляції R відображає зв'язок залежної змінної «задоволеність образом фізичного $Я$ » із сукупністю незалежних змінних та дорівнює 0,663 . Значення $\mathrm{R}^{2}$ становить 0,441 і показує, що 44,1\% дисперсії змінної «задоволеність образом фізичного Я» обумовлено впливом предикторів (умов). Кожна з незалежних змінних має позитивну кореляцію (R) iз залежною змінною.

Висновки і перспективи подальших розробок. Досліджено задоволеність образом фізичного Я за параметрами висоти самооцінки реального та ідеального образу фізичного Я, а також розбіжності між ними як прояв задоволеності/ незадоволеності зовнішністю. Аналіз конкретизував роль образів реальної та ідеальної зовнішності у визначенні рівня задоволеності зовнішністю, що залежить від адекватності висоти самооцінок.

Вивчено структуру самоставлення жінок раннього дорослого віку. Отримані дані засвідчили, що задоволеність образом фізичного Я впливає на загальне позитивне ставлення особистості до них чоловіків до своєї зовнішності). себе. Що вищий рівень задоволеності образом фізичного Я, то вищий рівень емоційних компонентів самоставлення: самоповаги, аутосимпатії, самоінтересу, очікуваного ставлення від навколишніх.

Дослідження рівня перфекціонізму показало, що досліджувані жінки, незалежно від рівня задоволеності образом фізичного Я, висувають високі стандарти особистості до себе, постійно оцінюють свою поведінку, прагнуть до досконалості, висувають високі стандарти і нереалістичні вимоги не тільки до себе, а й до інших.

Вивчено ступінь прояву основних показників психологічного благополуччя особистості (позитивні відносини з іншими, автономія, управління оточенням, особистісне зростання, мета в житті, самосприйняття). Отримані дані засвідчили, що задоволеність образом фізичного Я впливає на загальне психологічне благополуччя особистості. Що вищий рівень задоволеності образом фізичного Я, то вищий рівень психологічного благополуччя та його складників.

За допомогою множинного регресивного аналізу встановлено, що на позитивну самооцінку (задоволеність) образу фізичного Я прямо впливають компоненти психологічного благополуччя (самосприйняття, мета в житті, особистісне зростання), компоненти самоставлення (самоповага, самоінтерес) і перфекціонізму (перфекціонізм, орієнтований на себе). Під час дослідження підтверджено гіпотезу про те, що задоволеність образом фізичного Я у жінок раннього дорослого віку визначається комплексом взаємопов'язаних особистісних умов (позитивним самоставленням, проявом перфекціонізму, психологічним благополуччям особистості).

Проведене дослідження окреслило шляхи для подальшої розробки наукової проблематики (особистісна зумовленість задоволеності образом фізичного Я в інші періоди дорослості, гендерна специфіка у зв'язку з підвищеною увагою сучас-

\section{ЛІТЕРАТУРА}

1. Варлашкина Е.А. Личностные предикторы удовлетворенности образом физического Я у женщин в период зрелости : дисс. ... канд. психол. наук : 19.00.05. Ярославль, 2016. 171 с.

2. Гавриленко А.А. Образ физического Я как структурная составляющая Я-концепции : дисс. ... канд. психол. наук : 19.00.05. Москва, 2009. 175 с.

3. Лабунская В.А. «Видимый» человек как социально-психологический феномен. Социальная психология и общество. 2010. № 1. С. 26-39.

4. Левицька I.M. Дослідження тілесності у межах концепції образу фізичного «Я». Гуманітарний вісник ДВНЗ «Переяслав-Хмельнииький державний педагогічний університет ім. Григорія Сковороди». Тематичний випуск «Міжснародні Челпанівські психолого-педагогічні читання». Київ : Гнозис, 2017. Вип. 37 (3). Том II (22). С. 162-170.

5. Рамси Н., Харкорт Д. Психология внешности. Санкт-Петербург : Питер, 2009. 256 с.

6. Сахарова В.Г. Психология тела. Диагностика отношения к телу. Санкт-Петербург : Речь, 2011. 112 с.

7. Суэми В., Фернхем А. Психология красоты и привлекательности. Санкт-Петербург : Питер, 2009. 
$240 \mathrm{c}$.

8. Холмогорова А.Б., Даденко А.А. Физический перфекционизм как фактор расстройств аффективного спектра в современной культуре. Медичинская психология в России. 2010. № 3. URL: http://medpsy.ru

9. Черкашина А.Г. Образ физического Я в самоотношении девушек 17-18 лет : дисс. ... канд. психол. наук : 19.00.05. Самара, 2004. 197 с.

10. Шевченко Н.Ф. Теоретичні підходи до розуміння поняття «самоповага» в історичному поступі психологічного знання. Наука й освіта. 2015. № 11-12. С. 19-25.

11. Levytska I. The Empirical Reserch of the Influence of the Image of Phisical Oneself on Girls' Self-Attitude at an Early Adolescent Age. Zbiór artykułów naukowych z Konferencji Miedzynarodowej Naukowo Praktycznej zorganizowanej dla pracowników naukowych uczelni, jednostek naukowo-badawczych oraz badawczych z państw obszaru bytego Związku Radzieckiego oraz bytej Jugosławii. Warszawa, 2019. S. 66-69.

12. Sherry S.B., Hewitt P.L. Perfectionism and Thoughts About Having Cosmetic Surgery Performed. Journal of Applied Biobehavioral Research. 2004. № 9. P. 1-14.

\section{REFERENCES}

1. Varlashkina, Ye.A. (2016) Lichnostnyye prediktory udovletvorennosti obrazom fizicheskogo YA u zhenshchin v period zrelosti [Personal predictors of satisfaction with the image of the physical Self in women during maturity] : Candidate's thesis. Yaroslavl'. [in Russian]

2. Gavrilenko, A.A. (2009) Obraz fizicheskogo YA kak strukturnaya sostavlyayushchaya YA-kontseptsii [The image of the physical Self as a structural component of the Self-concept] : Candidate's thesis. Moscow. [in Russian]

3. Labunskaya, V.A. (2010) "Vidimyy" chelovek kak sotsial'no-psikhologicheskiy fenomen ["Visible" person as a socio-psychological phenomenon]. Sotsial'naya psikhologiya i obshchestvo. № 1, pp. 26-39. [in Russian]

4. Levyts'ka, I.M. (2017) Doslidzhennya tilesnosti u ramkakh kontseptsiyi obrazu fizychnoho "YA" [The study of corporeality in the concept of the image of the physical "Self"]. Humanitarnyy visnyk DVNZ "Pereyaslav-Khmel'nyts'kyy derzhavnyy pedahohichnyy univerytet imeni Hryhoriya Skovorody". Kyiv. № 37(3), II (22), pp. 162-170. [in Ukrainian]

5. Ramsi, N., Kharkort, D. (2009) Psikhologiya vneshnosti [Psychology of appearance]. Saint Petersburg : Piter. [in Russian]

6. Sakharova, V.G. (2011) Psikhologiya tela. Diagnostika otnosheniya k telu [Body psychology. Diagnostics of the attitude to the body]. Saint Petersburg : Rech'. [in Russian]

7. Suemi, V., Fernkhem, A. (2009) Psikhologiya krasoty i privlekatel'nosti [Psychology of beauty and attractiveness]. Saint Petersburg : Piter. [in Russian]

8. Kholmogorova, A.B., Dadenko, A.A. (2010) Fizicheskiy perfektsionizm kak faktor rasstroystv affektivnogo spektra $\mathrm{v}$ sovremennoy kul'ture [Physical perfectionism as a factor in affective spectrum disorders in modern culture]. Meditsinskaya psikhologiya v Rossii. № 3. URL: http://medpsy.ru. [in Russian]

9. Cherkashina, A.G. (2004) Obraz fizicheskogo YA v samootnoshenii devushek 17-18 let [The image of the physical Self in the self-attitude of girls 17-18 years old] : Candidate's thesis. Samara. [in Russian]

10. Shevchenko, N.F. (2015) Teoretychni pidkhody do rozuminnya ponyattya "samopovaha" v istorychnomu postupi psykholohichnoho znannya [Theoretical approaches to understanding the concept of "self-esteem" in the historical progress of psychological knowledge]. Nauka i osvita. № 11-12, pp. 19-25. [in Ukrainian]

11. Levytska, I. (2019) The Empirical Reserch of the Influence of the Image of Phisical Oneself on Girls' Self-Attitude at an Early Adolescent Age. Zbiór artykułów naukowych z Konferencji Miedzynarodowej Naukowo Praktycznej zorganizowanej dla pracowników naukowych uczelni, jednostek naukowo-badawczych oraz badawczych z państw obszaru bytego Zwiąku Radzieckiego oraz bylej Jugosławii. Warszawa. pp. 66-69.

12. Sherry, S.B., Hewitt, P.L. (2004) Perfectionism and Thoughts About Having Cosmetic Surgery Performed. Journal of Applied Biobehavioral Research. No. 9, pp. 1-14. 